\title{
Prognosis in Myelodysplastic Syndromes: The Clinical Challenge of Genomic Integration
}

\author{
Tzu-Hua Chen-Liang
}

Citation: Chen-Liang, T.-H. Prognosis in Myelodysplastic Syndromes: The Clinical Challenge of Genomic Integration. J. Clin. Med. 2021, 10, 2052. https://doi.org/ $10.3390 / \mathrm{jcm} 10102052$

Academic Editor: Fernando Ramos

Received: 15 March 2021

Accepted: 3 May 2021

Published: 11 May 2021

Publisher's Note: MDPI stays neutral with regard to jurisdictional claims in published maps and institutional affiliations.

Copyright: (C) 2021 by the author. Licensee MDPI, Basel, Switzerland. This article is an open access article distributed under the terms and conditions of the Creative Commons Attribution (CC BY) license (https:// creativecommons.org/licenses/by/ $4.0 /)$.
Hematology and Oncology Unit, University Hospital Morales Meseguer, Marques de los Velez s/n, 30008 Murcia, Spain; tzuchen82@gmail.com

\begin{abstract}
Myelodysplastic syndromes (MDS) are a group of clonal hematopoietic neoplasms characterized by ineffective hematopoiesis and myelodysplasia with a variable spectrum of clinicalbiological features that can be used to build a prognostic estimation. This review summarizes the current most widely used prognostic scoring systems and gives a general view of the prognostic impact of somatic mutations in MDS patients.
\end{abstract}

Keywords: prognostic impact; clinical-genetic alterations; myelodysplastic syndrome

\section{Introduction}

Since the publication of the International Prognosis Scoring System (IPSS) in 1997 [1], the international community has focused on finding the best scheme to delineate patient prognosis and cover all subcategories of this group of neoplasms. Nevertheless, with the advent of new massive sequencing tools and their constant improvement, we have a collection of genetic information in terms of the presence of mutations that may change former prognostic scores. Prognostic tools, although designed for most medical conditions, perform better in entities with a heterogeneous clinical course. Myelodysplastic syndromes (MDS) are arguably the most heterogeneous entity among hematological neoplasms. Every day in hematologist waiting rooms, we find patients with the same diagnostic label but very different plans of treatment, from wait-and-watch visits every six months with just an automatized blood count to patients going through the extremely complex road of an allogenic hematopoietic transplantation.

This review summarizes the current most widely used prognostic scoring systems and illustrates the importance of uniting information about different genetic aberrations with clinical features to provide the best understanding of MDS prognostication.

\subsection{Past and Present MDS Prognostic Models}

In daily clinical practice, current prognostic scoring systems are built up from two types of factors: patient (or host) and MDS-related [2]. Patient-related factors may include inherent demographic characteristics as age, gender, ethnicity. Other variables, such as performance status (PS), comorbidities or immune status, are also included here. However, only age and PS are considered to date as correction factors for survival estimation in the most widely used score, IPSS-R. With regard to MDS-related factors, peripheral blood and bone marrow features constitute the main source of predictors. In this category, cytogenetics stands as the most relevant factor in IPSS-R (Figure 1).

Each prognostic score developed in the MDS setting has its strengths and weaknesses. We elaborating about it below, focusing on three still unresolved entities: therapy-related MDS, hypoplastic, and MDS with myelofibrosis [3]. 


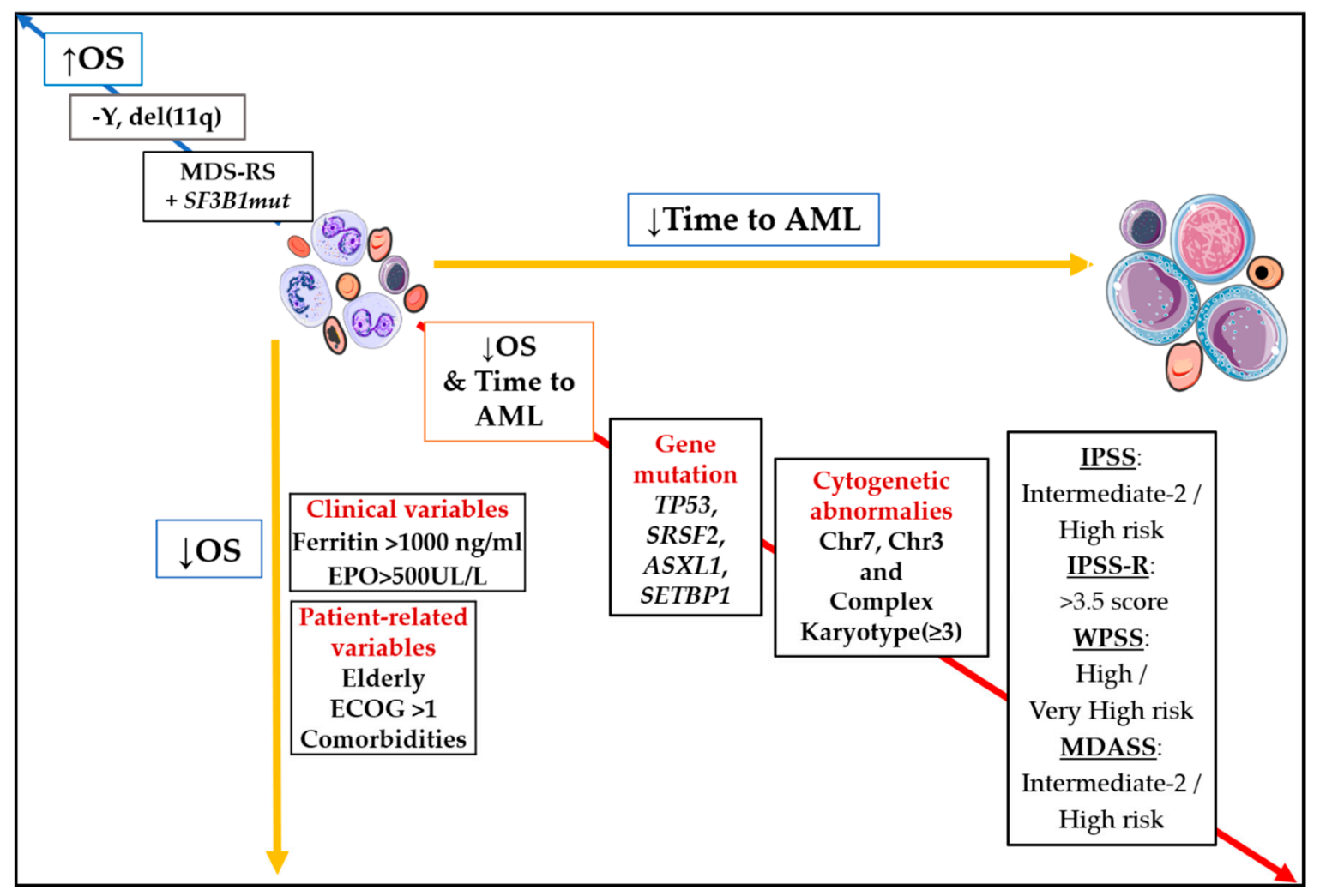

Figure 1. Impact of main prognostic markers on overall survival (OS) and time to acute myeloid leukemia (AML). Diagonal red arrow indicates factors associated both with worse OS and shorter time to AML. Opposite blue arrow is pointing out main factors are associated with better survival. Abbreviations: AML, acute myeloid leukemia; OS, overall survival; Chr, chromosome; EPO, erythropoietin; ECOG, Eastern Cooperative Oncology Group; MDS-RS, myelodysplastic syndrome with ring sideroblasts; $-\mathrm{Y}$, monosomy $\mathrm{Y}$; $\operatorname{del}(11 \mathrm{q})$, deletion of long arm of chromosome $11 ; \downarrow$, inferior; $\uparrow$; superior.

\subsection{The Classical System and Its Modifications}

The International Prognostic Scoring System (IPSS) was established from a combination of previous data on seven scoring systems involving 816 primary MDS patients [1]. Patients who had previously received intensive chemotherapy and those with secondary MDS were excluded. In the final scoring, bone marrow blast percentage, cytogenetic aberrations, and the number of cytopenias were considered. With these variables, authors categorized 4 subgroups: low, intermediate-1, intermediate-2, and high in consideration of the time to acute myeloid leukemia (AML) and overall survival (OS) (Table 1).

The indisputable prognostic value and simplicity of its use made the IPSS to be widely adopted. As it was the cornerstone of MDS outcome prediction for a decade and a half, certain pitfalls were indicated by different groups and researchers. In the pivotal IPSS study, patients were diagnosed according to French-American-British (FAB) criteria. Hence, the final analysis included MDS with $21 \%$ to $30 \%$ bone-marrow myeloblasts and non-proliferative chronic myelomonocytic leukemia (less than $12,000 / \mu \mathrm{L}$ white-bloodcell (WBC) count), both entities no longer considered among MDS categories in later WHO classifications. Age (60 years or more) did not make it to the final score, as its prognostic significance was demonstrated for OS, but not for time to AML [1]. Other exposed shortcomings included not considering cytopenia depth and not assessing the score value when calculated throughout the course of the disease.

Several modified IPSS models were proposed to improve its applicability, and extend its utility to other groups of patients and disease contexts [3,4]. The WHO scoring system took advantage of the prognostic impact of the diagnostic categories and incorporated the severity of anemia. This score showed us that the number of lineages mattered in the 
prognostic setting and it was validated not only at diagnosis but also throughout the course of the disease, making it a dynamic score (Table 2).

Table 1. International Prognostic Scoring System. Adapted from Greenberg et al., Blood, 1997 [1].

\begin{tabular}{|c|c|c|c|c|c|c|}
\hline Variable & Parameter & Score & Final Score & Risk Group & $\begin{array}{l}\text { LFS Median } \\
\text { (Years) }\end{array}$ & $\begin{array}{l}\text { OS Median } \\
\text { (Years) }\end{array}$ \\
\hline \multirow{4}{*}{ Blasts in bone marrow (\%) } & $<5$ & 0 & \multirow{3}{*}{0} & \multirow{3}{*}{ Low } & \multirow{3}{*}{9.4} & \multirow{3}{*}{5.7} \\
\hline & $5-10$ & 0.5 & & & & \\
\hline & $11-20$ & 1.5 & & & & \\
\hline & $21-30$ & 2 & \multirow{2}{*}{$0.5-1$} & \multirow{2}{*}{ Intermediate-1 } & \multirow{2}{*}{3.3} & \multirow{2}{*}{3.5} \\
\hline \multirow{3}{*}{ Cytogenetic aberrations } & Normal, del(5q), del(20q) & 0 & & & & \\
\hline & Other alterations & 0.5 & \multirow{2}{*}{$1.5-2$} & \multirow{2}{*}{ Intermediate-2 } & \multirow{2}{*}{1.1} & \multirow{2}{*}{1.2} \\
\hline & 3 or more alterations, Chrom 7 aberrations & 1 & & & & \\
\hline \multirow{2}{*}{ Number of cytopenias * } & None or 1 & 0 & \multirow[t]{2}{*}{$\geq 2.5$} & \multirow[t]{2}{*}{ High } & \multirow[t]{2}{*}{0.2} & \multirow[t]{2}{*}{0.4} \\
\hline & 2 or 3 & 0.5 & & & & \\
\hline
\end{tabular}

${ }^{*}$ Hemoglobin $<10 \mathrm{~g} / \mathrm{dL}$, absolute neutrophile count $<1800 / \mu \mathrm{L}$, platelets < 100,000/ $\mu \mathrm{L}$. Abbreviations: LFS, leukemia free survival; OS, overall survival.

Table 2. World Health Organization classification-based Prognostic Scoring System (WPSS). Adapted from Malcovati et al., Journal of Clinical Oncology, 2007 [5].

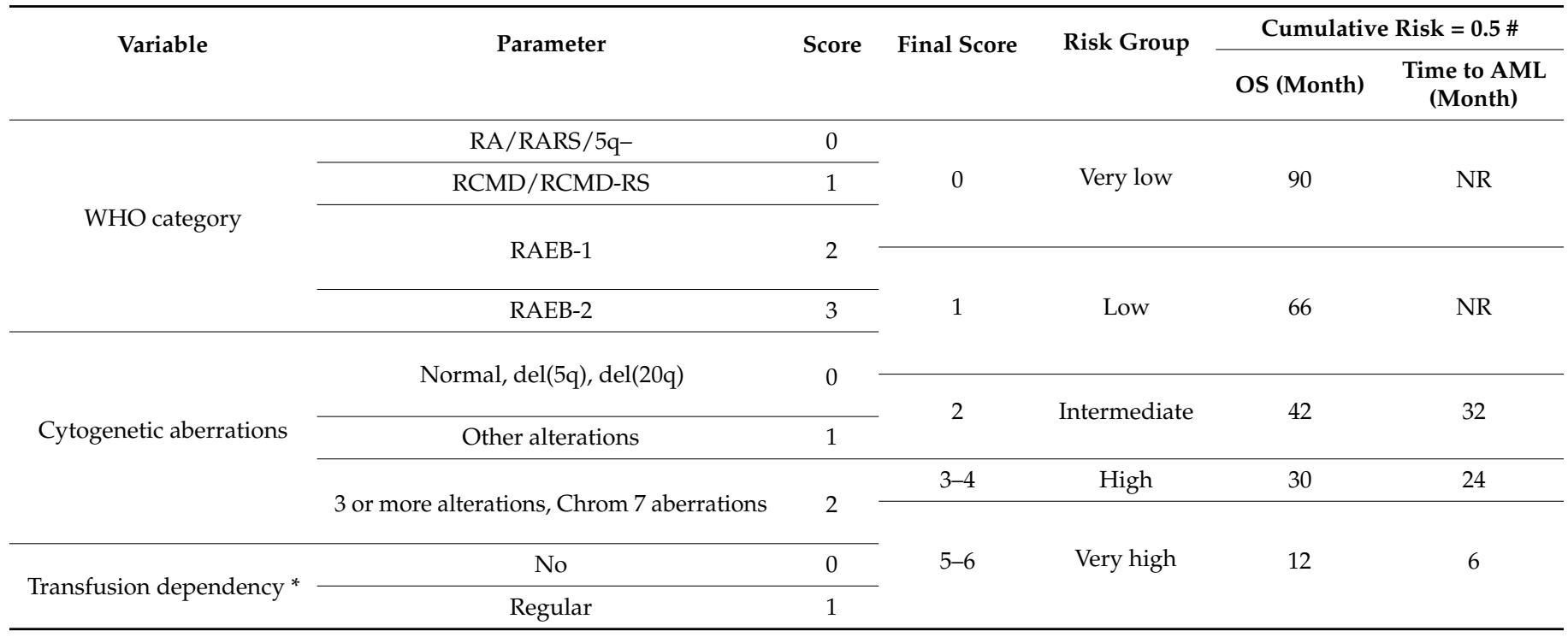

* Red-blood-cell (RBC) transfusion dependency defined as having at least one RBC transfusion every 8 weeks over a period of 4 months. Hemoglobin concentration less than $90 \mathrm{~g} / \mathrm{L}$ in males and $80 \mathrm{~g} / \mathrm{L}$ in females was later considered an appropriate surrogate for transfusion dependency. \# Approximate values after interpretation of figures from the article of Malcovati et al. In the very low and low risk categories, plateau was reached before 0.5 cumulative risk of AML. Abbreviations: RA, refractory anemia; RARS, refractory anemia with ringed sideroblasts; RCMD, refractory cytopenia with multilineage dysplasia; RCMD-RS, refractory cytopenia with multilineage dysplasia and ringed sideroblasts; RAEB-1, refractory anemia with excess of blasts-1; RAEB-2, refractory anemia with excess of blasts-2; MDS del(5q), myelodysplastic syndrome with isolated $\operatorname{del}(5 q)$ and marrow blasts less than $5 \%$; NR, nonreached.

The MD Anderson's cancer group designed a scoring system to refine the prognosis of patients included in the low and intermediate 1 IPSS categories, making severe thrombocytopenia a key prediction factor. In addition, they created a comprehensive score system where they incorporated subsets not included (proliferative chronic myeloid monocytic leukemia, therapy-related MDS and previously treated cases) and factors not considered [Eastern Cooperative Oncology Group (ECOG), age, prior red-blood-cell transfusion] in the original IPSS (Table 3) [3]. 
Table 3. MD Anderson Prognostic Scoring System (MDASS). Adapted from Kantarjian et al., Cancer, 2008 [3].

\begin{tabular}{|c|c|c|c|c|c|}
\hline Variable & Parameter & Score & Final Score & Risk Group & $\begin{array}{l}\text { OS Median } \\
\text { (Months) }\end{array}$ \\
\hline Performance status & $>2$ & 2 & \multirow{3}{*}{$0-4$} & \multirow{3}{*}{ Low } & \multirow{3}{*}{54} \\
\hline \multirow{2}{*}{ Age, years } & $60-64$ & 1 & & & \\
\hline & $\geq 65$ & 2 & & & \\
\hline \multirow{3}{*}{ Platelets, $\times 10^{9} / \mathrm{L}$} & 50-199 & 1 & \multirow{4}{*}{$5-6$} & \multirow{4}{*}{ Intermediate 1} & \multirow{4}{*}{25} \\
\hline & $30-49$ & 2 & & & \\
\hline & $<30$ & 3 & & & \\
\hline Hemoglobin, g/dL & $<12$ & 2 & & & \\
\hline \multirow{2}{*}{ Bone marrow blasts, $\%$} & $5-10$ & 1 & \multirow{3}{*}{$7-8$} & \multirow{3}{*}{ Intermediate 2} & \multirow{3}{*}{14} \\
\hline & $11-29$ & 2 & & & \\
\hline WBC, $\times 10^{9} / \mathrm{L}$ & $>20$ & 2 & & & \\
\hline Karyotype & Chr 7 abnormalities or complex abnormalities $(\geq 3)$ & 3 & \multirow{2}{*}{$9-15$} & \multirow{2}{*}{ High } & \multirow{2}{*}{6} \\
\hline Prior transfusion & Yes & 1 & & & \\
\hline
\end{tabular}

Abbreviations: WBC, white blood cell; OS, overall survival; Chr, chromosome.

\subsection{Revised System}

The revised IPSS (IPSS-R) was generated from the evaluation of 7012 patients, and the three classical IPSS building blocks remained: bone-marrow blast percentage, cytogenetics, and cytopenias. Nevertheless, its accuracy was improved both because of a larger population source and because it refined the three blocks. First, the depth of cytopenias was taken into account, adding more points in the final score when anemia, neutropenia, and thrombocytopenia are more severe. Second, cytogenetic categories were further stratified in five subgroups, with the highest stratum showing more weight than that in the bone-marrow blast proportion. Third, the lower blast-percentage categories were divided into two. IPSS$\mathrm{R}$ classifies 5 well separated prognostic categories (very low, low, intermediate, high, and very high) according to OS and time to AML risk (Table 4) [6]. Much like its predecessor, the IPSS-R has become the mainstream score in the MDS field. It is slightly more difficult to calculate than the classical method is, and some online calculators are availableforclinicians (https:/ / www.mds-foundation.org/ipss-r-calculator/, https:/ /www.mdcalc.com/ revised-international-prognostic-scoring-system-ipss-r-myelodysplastic-syndrome-mds (accessed on 11 May 2021)).

It soon became apparent that the revised version significantly improved risk stratification in MDS patients [7]. However, in daily clinical routine, therapeutic algorithms in MDS separate patients into two groups, low- and high-risk. With the advent of the revised version and its five categories, it was clear that a unique intermediate category was needed. Pfeilstocker et al. proposed to split the score by a $\leq 3.5$ point cut-off for therapeutical purposes [8].

Some factors were proposed to add independent prognostic value to the IPSS-R: ferritin, hypoalbuminemia, flow-cytometry profile, b2-microglobulin, LDH, or performance status were shown by different groups to be of value $[9,10]$. Some of these factors showed a low independent predictive weight for OS, but not for time to AML in the IPSS-R pivotal study [6]. Other groups focused their interest on the intermediate category, aiming at its division, allowing for global score stratification in two groups due to the aforementioned routine therapeutic consideration. The use of bone-marrow CD34 positive percentage or the enumeration of blasts exclusively from the myeloid compartment has proven to be useful in some studies [11,12]. Bone-marrow fibrosis (BMF) was an independent factor when confronted with the classical score [13]. In this study of 301 patients with MDS, patients with grades $\geq 2$ BMF had shorter OS and leukemia-free survival (LFS) compared to those with grades $\leq 1 \mathrm{BMF}$. The prognostic impact was independent of presence of excess of blasts. Later, BMF was shown to correlate with worse survival within MDS patients who 
underwent an allogeneic hematopoietic stem cell transplantation [14]. In the IPSS-R era, Ramos et al. reported that advanced myelofibrosis was associated with the presence of mutations in cohesin complex genes and inferior survival [15]. The controversy about when to perform a biopsy (some diagnostic schools avoid the systematic use of this invasive procedure) has precluded this parameter to be assessed in the pivotal series.

Table 4. Revised IPSS. Adapted from Greenberg et al., Blood, 2012 [6].

\begin{tabular}{|c|c|c|c|c|c|c|c|}
\hline Variable & Sco & & & Final Score & $\begin{array}{l}\text { Risk } \\
\text { Group }\end{array}$ & $\begin{array}{l}\text { Median Time } \\
\text { to AML } \\
\text { (Years) }\end{array}$ & $\begin{array}{l}\text { OS, Median } \\
\quad \text { (Years) }\end{array}$ \\
\hline \multirow{4}{*}{$\begin{array}{l}\text { Blasts in bone } \\
\text { marrow }(\%)\end{array}$} & \multicolumn{2}{|l|}{$<2$} & 0 & & & & \\
\hline & \multicolumn{2}{|c|}{$>2$ to $<5$} & 1 & & & & \\
\hline & \multicolumn{2}{|l|}{$5-10$} & 2 & $\leq 1.5$ & Very low & NR & 8.8 \\
\hline & \multicolumn{2}{|l|}{$>10$} & 3 & & & & \\
\hline \multirow{5}{*}{$\begin{array}{l}\text { Cytogenetic } \\
\text { aberrations }\end{array}$} & \multicolumn{2}{|c|}{$-Y, \operatorname{del}(11 q)$} & 0 & & & & \\
\hline & \multicolumn{2}{|c|}{$\begin{array}{l}\text { Normal, del }(5 q), \operatorname{del}(12 p), \operatorname{del}(20 q), \text { double } \\
\text { including } \operatorname{del}(5 q)\end{array}$} & 1 & $2-3$ & Low & 10.8 & 5.3 \\
\hline & \multicolumn{2}{|c|}{$\begin{array}{c}\operatorname{del}(7 q),+8,+19, i(17 q) \text {, any other single or double } \\
\text { independent clones }\end{array}$} & 2 & & & & \\
\hline & \multicolumn{2}{|c|}{$\begin{array}{l}-7 \text {, inv }(3) / t(3 q) / \operatorname{del}(3 q) \text {, double including } \\
-7 / \operatorname{del}(7 q) \text {, complex: } 3 \text { abnormalities }\end{array}$} & 3 & $3.5-4.5$ & Intermediate & 3.2 & 3 \\
\hline & \multicolumn{2}{|c|}{ Complex: >3 abnormalities } & 4 & \multirow{5}{*}{$5-6$} & \multirow{5}{*}{ High } & \multirow{5}{*}{1.4} & \multirow{5}{*}{1.6} \\
\hline \multirow{8}{*}{ Cytopenia } & \multirow{3}{*}{$\mathrm{Hb}(\mathrm{g} / \mathrm{dL})$} & $\geq 10$ & 0 & & & & \\
\hline & & $8-10$ & 1 & & & & \\
\hline & & $<8$ & 1.5 & & & & \\
\hline & \multirow{3}{*}{ Platelets $\left(\times 10^{9} / \mathrm{L}\right)$} & $>100$ & 0 & & & & \\
\hline & & $50-<100$ & 0.5 & \multirow{4}{*}{$\geq 6.5$} & \multirow{4}{*}{ Very High } & \multirow{4}{*}{0.7} & \multirow{4}{*}{0.8} \\
\hline & & $<50$ & 1 & & & & \\
\hline & \multirow{2}{*}{$\mathrm{ANC}\left(\times 10^{9} / \mathrm{L}\right)$} & $>0.8$ & 0 & & & & \\
\hline & & $<0.8$ & 0.5 & & & & \\
\hline
\end{tabular}

Abbreviations: AML, acute myeloid leukemia; OS, overall survival; NR, non-reached, Hb, hemoglobin; ANC, absolute neutrophil count.

\section{Incoming MDS Prognostic Models}

Next-generation sequencing has allowed for large-scale analysis of the molecular profile in MDS. Not surprisingly, its mutational landscape is quite heterogeneous, something that is considered critical to define MDS clinical and pathological features since its first description. The collection of NGS data has granted significant knowledge about the pathophysiological complexity of this blood cancer, involving a set of recurrently mutated genes that play diverse roles in cellular processes, such as DNA methylation, chromatin modification, signal transduction, transcriptional regulation, and RNA splicing $[5,7,8,16,17]$. Among patients diagnosed with MDS, more than $50 \%$ have normal cytogenetics, the only genomic variable included in current prognostic scores, but about $90 \%$ harbor mutations. The mutational burden is directly correlated with the number of karyotypic aberrations. Still, a high percentage of low-risk and normal karyotype cases present with an average of 1-3 somatic mutations $[18,19]$.

From a strict quantitative view, the more acquired variants, the more likely the MDS to behave aggressively. Both Bejar and Papaemmanuil showed in a large series of MDS cases that stratification by the number of tumor mutations was highly predictive of LFS. Harboring three or more acquired mutations defined a subset of cases with approximately two years to leukemia transformation $[20,21]$. Haferlach et al. showed differences in the 
number of mutations across MDS subtype, from $60 \%$ of cases with four or more mutations in the MDS with excess of blasts- 2 subgroup to approximately $15 \%$ in the MDS with ring sideroblasts subgroup [5].

Another quantitative parameter, the variant allele frequency (VAF), has been studied for prognostic purposes. VAF depicts the percentage of mutated cells within the sample, and it is used as a surrogate marker to define clonal (predominant) or subclonal tumor population. However, for the VAF to be considered as a prognostic factor, the gene affected must be taken into account. TP53, TET2 and SF3B1 prognostic impact has been shown to be modified by the VAF. On the other hand, there are other targets, i.e., NRAS and EZH2, that seems to predict for more aggressive course regardless of the VAF [22-25].

Seven genes were previously reported to harbor independent prognostic significance in MDS and impact on OS: TP53, EZH2, RUNX1, NRAS, ASXL1 and SF3B1. All of them, regardless of $S F 3 B 1$, have negative influence on survival and could actively participate as triggers of disease progression to AML $[20,26,27]$. However, not a single or group of gene mutations were included in the IPSS-R (Figure 1).

TP53 is a tumor-suppressor gene that plays an essential role in cell-cycle arrest, DNA repair mechanisms, apoptosis induction, and cellular differentiation in response to genetic damage [28]. The mutation of TP53 is observed in approximately $10-15 \%$ of patients with MDS, and predicts for a dismal clinical outcome and poorer responses to treatment $[19,29,30]$. It is frequently present in complex karyotype cases, where survival is the shortest (less than six months) among MDS patients [28,31,32]. The isolated deletion of the long arm of chromosome 5 is generally considered a favorable feature and key for a good response to lenalidomide. However, it appears that the coexistence of this chromosomal aberration with a TP53 mutation worsens prognosis and contributes to an earlier relapse after treatment with lenalidomide [33-35].

Regarding the allele state of TP53, a recent study reported robust association between TP53 biallelic/multihit mutations and an inferior clinical outcome in MDS, in contrast to patients with a unique hit. Strikingly, the authors did not find any difference in OS between patients who had a single hit and those with intact TP53 [25]. Moreover, Sallman et al. found that MDS patients with the TP53 somatic mutation and VAF of $>40 \%$ had inferior OS (median 124 days) in comparison with those with VAF $<20 \%$ (median OS not reached) [22].

ASXL1 is mutated in 13-21\% of MDS cases, and its presence was described as a predictor of inferior survival in patients with low or intermediate-1 risk according to the IPSS [20]. SF3B1 is a RNA splicing machinery member, the only gene of which the acquired lesion defines a WHO category (MDS with ring sideroblasts) [36], and its mutational status is associated with improved OS [37], independent after adjustment by IPSS-R group [21]. RUNX1 is a crucial component of normal hematopoiesis, participating in hematopoietic stem-cell genesis and differentiation. It is mutated in nearly $10 \%$ of MDS cases. Patients with a lesion in RUNX1 have significantly inferior OS compared to those without it $[16,20,21,38]$. Before NGS was available, it had already been proven that the presence of a RUNX1 mutation in therapy-related MDS was related to shorter time to AML, but not to impact on OS [39].

As the frequency of cases mutated for a specific gene decreases, associations with a predictive value become blurrier. That is the case, for example, for IDH1, IDH2, EZH2, CBL and $U 2 A F 1$, with contradictory results. A peculiar case involves TET2, one of the more frequently mutated genes, directly responsible for the impairment of a critical pathway in this disease, but without definitive data regarding its prognostic value and its competence to predict for responses to hypomethylating agents (Table 5). 
Table 5. Somatic mutations and their association with clinical prognostic impact on outcome of myelodysplastic syndrome.

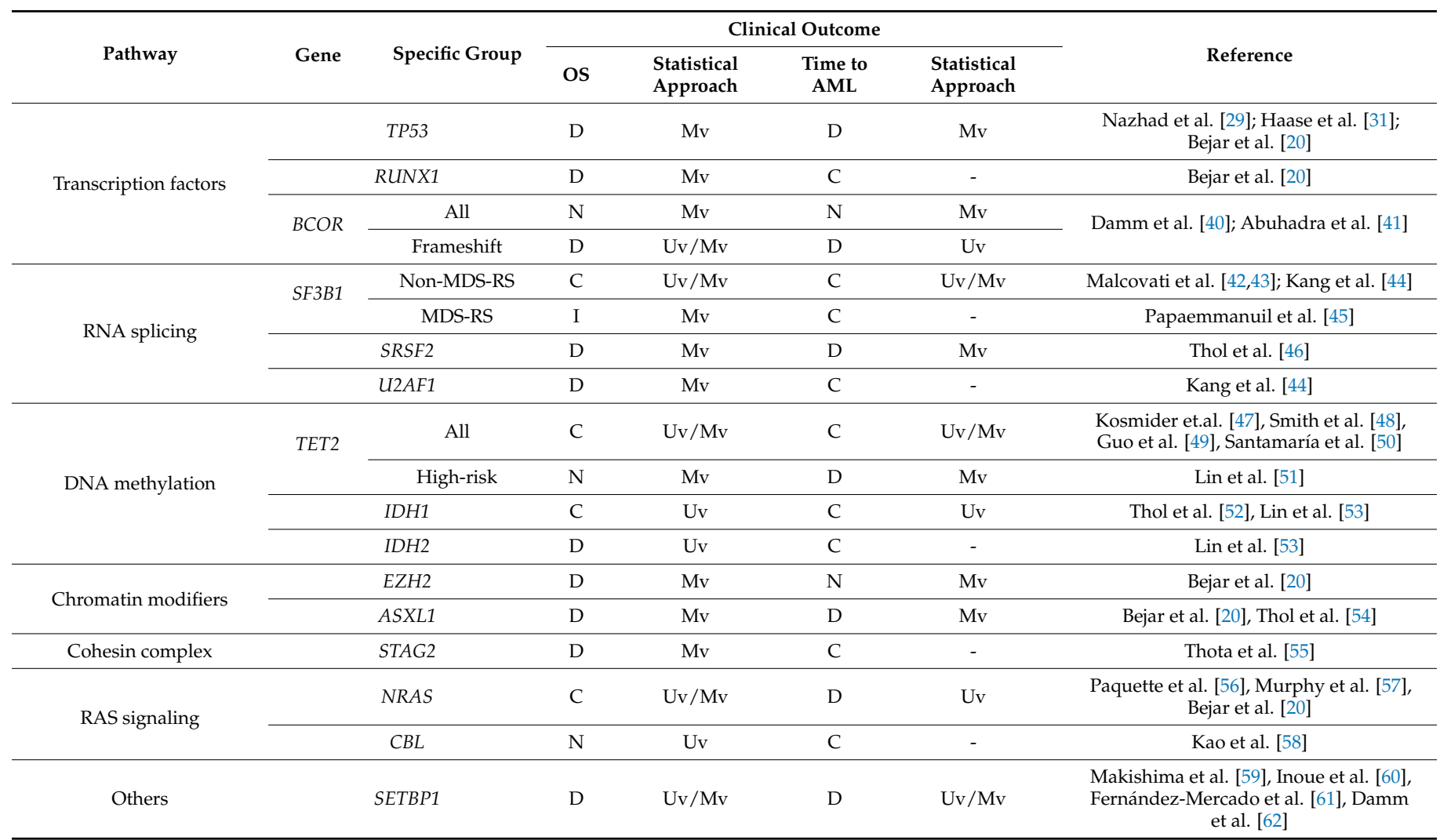

Abbreviations: OS, overall survival; AML, acute myeloid leukemia; D, decrease; I, increase; C, conflicting results; N, neutral; Mv, multivariate; Uv, Univariate; MDS-RS, myelodysplastic syndrome with ring sideroblasts. “-“: not available.

Using more refined statistical approaches, a recent study addressed the likely underestimated importance of mutation co-occurrence patterns in MDS prognostic settings [63]. Though external validation is needed, the authors stated that specific comutation patterns account for clinical heterogeneity within SF3B1, SRSF2, and del5q MDS. In addition, acquired mutations may be useful for both anticipating the natural history of the disease at diagnosis, and minimal residual disease assessment and prediction of progression during the course of MDS [64-66]. Lastly, the success or failure of emerging targeted therapies (i.e., $I D H 1 / 2$ or spliceosome inhibitors) may accelerate the implementation of new genes in the workup on MDS patients. Huge effort is currently expended to reach a molecular IPSS-R.

\section{New Approaches: Machine Learning, Big Data, and "Omics" Integration}

Machine learning is a branch of computer science that generates predictive or descriptive models by automatically learning through experience rather than being programmed a priori. Machine learning's competence to learn from data makes it especially suitable to model complex or nonlinear data. Progress in this field is behind the spectacular advances of recent speech translators and face-recognition applications. Among hematological malignancies, MDS could entail the most complex and heterogeneous clinical and laboratory data. Using machine learning, Nazha and colleagues could improve the discrimination ability of current prognostic scores in the uncharted context of a post-treatment setting [67] Whether automated algorithms, able to objectively operate with thousands of variables for a single individual, will substitute current scores mostly depends on the accuracy, size, and strict follow-up updates of training databases. International platforms were developed with the aim of gathering clinical-genetic information of patients with blood cancer into one single database from individual cases included in clinical trials and registries. The Harmony alliance, a pan-European public-private partnership, aims to reach statistical power to reveal how molecular data and treatments are intertwined. 
To holistically understand the complex clinical and biological disease of MDS, a combination of multiomic data that are able to shed light on the relationship between biomolecules, their function, and their coding and modulating components is imperative. As Winter et al. recently remarked, the integration of immunome (inflammatory cytokines, genes linked to the inflammasome, cellular responses and bone marrow microenvironment factors) with clinical variables is of particular interest in MDS patients, as more data add relevance to the role of immune dysregulation in MDS pathophysiology [68].

\section{Conclusions and Concerns}

Some questions remain for the accurate use of acquired mutations in prognostic systems: Does a specific variant feature (localization, activating or hypomorphic, mono- or biallelic) alter the prognostic value within a very gene? Does the hierarchical place of the mutation (clonal or subclonal) change the prognostic value of an altered gene? How is the prognostic fate of the presence of a mutated gene affected by targeted therapy? Can the co-occurrence of a determined set of mutations predict for a specific outcome? How can we smoothly incorporate comorbidities and performance status into the incoming prognostic models? The answers to these questions will guide us to the final goal of personalized prognostication in a disease that urgently needs new and satisfactory treatments.

Funding: This research received no external funding.

Conflicts of Interest: The author declares no conflict of interest.

\section{References}

1. Greenberg, P.; Cox, C.; LeBeau, M.M.; Fenaux, P.; Morel, P.; Sanz, G.; Sanz, M.; Vallespi, T.; Hamblin, T.; Oscier, D.; et al. International scoring system for evaluating prognosis in myelodysplastic syndromes. Blood 1997, 89, 2079-2088. [CrossRef] [PubMed]

2. Shreve, J.; Nazha, A. Novel Prognostic Models for Myelodysplastic Syndromes. Hematol. Oncol. Clin. N. Am. 2020, 34, 369-378. [CrossRef]

3. Kantarjian, H.; O'Brien, S.; Ravandi, F.; Cortes, J.; Shan, J.; Bennett, J.M.; List, A.; Fenaux, P.; Sanz, G.; Issa, J.-P.; et al. Proposal for a new risk model in myelodysplastic syndrome that accounts for events not considered in the original International Prognostic Scoring System. Cancer 2008, 113, 1351-1361. [CrossRef] [PubMed]

4. Schanz, J.; Tüchler, H.; Solé, F.; Mallo, M.; Luño, E.; Cervera, J.; Granada, I.; Hildebrandt, B.; Slovak, M.L.; Ohyashiki, K.; et al. New Comprehensive Cytogenetic Scoring System for Primary Myelodysplastic Syndromes (MDS) and Oligoblastic Acute Myeloid Leukemia after MDS Derived from an International Database Merge. J. Clin. Oncol. 2012, 30, 820-829. [CrossRef] [PubMed]

5. Malcovati, L.; Germing, U.; Kuendgen, A.; Della Porta, M.G.; Pascutto, C.; Invernizzi, R.; Giagounidis, A.; Hildebrandt, B.; Bernasconi, P.; Knipp, S.; et al. Time-dependent prognostic scoring system for predicting survival and leukemic evolution in myelodysplastic syndromes. J. Clin. Oncol. 2007, 25, 3503-3510. [CrossRef]

6. Greenberg, P.L.; Tuechler, H.; Schanz, J.; Sanz, G.; Garcia-Manero, G.; Solé, F.; Bennett, J.M.; Bowen, D.; Fenaux, P.; Dreyfus, F.; et al. Revised international prognostic scoring system for myelodysplastic syndromes. Blood 2012, 120, 2454-2465. [CrossRef]

7. Della Porta, M.G.; Tuechler, H.; Malcovati, L.; Schanz, J.; Sanz, G.; Garcia-Manero, G.; Solé, F.; Bennett, J.M.; Bowen, D.; Fenaux, P.; et al. Validation of WHO classification-based Prognostic Scoring System (WPSS) for myelodysplastic syndromes and comparison with the revised International Prognostic Scoring System (IPSS-R). A study of the International Working Group for Prognosis in Myelodyspla. Leukemia 2015, 29, 1502-1513. [CrossRef]

8. Pfeilstöcker, M.; Tuechler, H.; Sanz, G.; Schanz, J.; Garcia-Manero, G.; Solé, F.; Bennett, J.M.; Bowen, D.; Fenaux, P.; Dreyfus, F.; et al. Time-dependent changes in mortality and transformation risk in MDS. Blood 2016, 128, 902-910. [CrossRef] [PubMed]

9. Komrokji, R.S.; Corrales-Yepez, M.; Kharfan-Dabaja, M.A.; Al Ali, N.H.; Padron, E.; Rollison, D.E.; Pinilla-Ibarz, J.; Zhang, L.; Epling-Burnette, P.K.; Lancet, J.E.; et al. Hypoalbuminemia is an independent prognostic factor for overall survival in myelodysplastic syndromes. Am. J. Hematol. 2012, 87, 1006-1009. [CrossRef] [PubMed]

10. van de Loosdrecht, A.A.; Ireland, R.; Kern, W.; Della Porta, M.G.; Alhan, C.; Balleisen, J.S.; Bettelheim, P.; Bowen, D.T.; Burbury, K.; Eidenschink, L.; et al. Rationale for the clinical application of flow cytometry in patients with myelodysplastic syndromes: Position paper of an International Consortium and the European LeukemiaNet Working Group. Leuk. Lymphoma 2013, 54, 472-475. [CrossRef]

11. Chen-Liang, T.-H.; Casado-Prieto, A.M.; Campos-Rodríguez, V.; Hurtado, A.M.; Amigo, M.L.; García-Malo, M.D.; Vicente, V.; Ortuño, F.J; Jerez, A. An increased percentage of myeloid CD34+ bone marrow cells stratifies intermediate IPSS-R myelodysplastic syndrome patients into prognostically significant groups. Int. J. Lab. Hematol. 2018, 40, 549-555. [CrossRef] [PubMed] 
12. Calvo, X.; Arenillas, L.; Luño, E.; Senent, L.; Arnan, M.; Ramos, F.; Pedro, C.; Tormo, M.; Montoro, J.; Díez-Campelo, M.; et al. Enumerating bone marrow blasts from nonerythroid cellularity improves outcome prediction in myelodysplastic syndromes and permits a better definition of the intermediate risk category of the Revised International Prognostic Scoring System (IPSS-R). Am. J. Hematol. 2017, 92, 614-621. [CrossRef] [PubMed]

13. Porta, M.G.D.; Malcovati, L.; Boveri, E.; Travaglino, E.; Pietra, D.; Pascutto, C.; Passamonti, F.; Invernizzi, R.; Castello, A.; Magrini, U.; et al. Clinical relevance of bone marrow fibrosis and CD34-positive cell clusters in primary mvelodvsplastic syndromes. J. Clin. Oncol. 2009, 27, 754-762. [CrossRef]

14. Fu, B.; Jaso, J.M.; Sargent, R.L.; Goswami, M.; Verstovsek, S.; Medeiros, L.J.; Wang, S.A. Bone marrow fibrosis in patients with primary myelodysplastic syndromes has prognostic value using current therapies and new risk stratification systems. Mod. Pathol. 2014, 27, 681-689. [CrossRef]

15. Ramos, F.; Robledo, C.; Izquierdo-García, F.M.; Suárez-Vilela, D.; Benito, R.; Fuertes, M.; Insunza, A.; Barragán, E.; Del Rey, M.; García-Ruiz de Morales, J.M.; et al. Bone marrow fibrosis in myelodysplastic syndromes: A prospective evaluation including mutational analysis. Oncotarget 2016, 7, 30492-30503. [CrossRef] [PubMed]

16. Haferlach, T.; Nagata, Y.; Grossmann, V.; Okuno, Y.; Bacher, U.; Nagae, G.; Schnittger, S.; Sanada, M.; Kon, A.; Alpermann, T.; et al Landscape of genetic lesions in 944 patients with myelodysplastic syndromes. Leukemia 2014, 28, 241-247. [CrossRef]

17. Makishima, H.; Yoshizato, T.; Yoshida, K.; Sekeres, M.A.; Radivoyevitch, T.; Suzuki, H.; Przychodzen, B.; Nagata, Y.; Meggendorfer, M.; Sanada, M.; et al. Dynamics of clonal evolution in myelodysplastic syndromes. Nat. Genet. 2017, 49, 204-212. [CrossRef]

18. Nazha, A.; Komrokji, R.S.; Garcia-Manero, G.; Barnard, J.; Roboz, G.J.; Steensma, D.P.; DeZern, A.E.; Zell, K.; Zimmerman, C.; Al Ali, N.; et al. The efficacy of current prognostic models in predicting outcome of patients with myelodysplastic syndromes at the time of hypomethylating agent failure. Haematologica 2016, 101, e224-e227. [CrossRef]

19. Fenaux, P.; Platzbecker, U.; Ades, L. How we manage adults with myelodysplastic syndrome. Br. J. Haematol. 2020, 189 , 1016-1027. [CrossRef]

20. Bejar, R.; Stevenson, K.; Abdel-Wahab, O.; Galili, N.; Nilsson, B.; Garcia-Manero, G.; Kantarjian, H.; Raza, A.; Levine, R.L.; Neuberg, D.; et al. Clinical Effect of Point Mutations in Myelodysplastic Syndromes. N. Engl. J. Med. 2011, 364, $2496-2506$. [CrossRef] [PubMed]

21. Papaemmanuil, E.; Gerstung, M.; Malcovati, L.; Tauro, S.; Gundem, G.; Van Loo, P.; Yoon, C.J.; Ellis, P.; Wedge, D.C.; Pellagatti, A.; et al. Clinical and biological implications of driver mutations in myelodysplastic syndromes. Blood 2013, 122, 3616-3627. [CrossRef]

22. Sallman, D.A.; Komrokji, R.; Vaupel, C.; Cluzeau, T.; Geyer, S.M.; McGraw, K.L.; Al Ali, N.H.; Lancet, J.; McGinniss, M.J.; Nahas, S.; et al. Impact of TP53 mutation variant allele frequency on phenotype and outcomes in myelodysplastic syndromes. Leukemia 2016, 30, 666-673. [CrossRef] [PubMed]

23. Hirsch, C.M.; Nazha, A.; Kneen, K.; Abazeed, M.E.; Meggendorfer, M.; Przychodzen, B.P.; Nadarajah, N.; Adema, V.; Nagata, Y.; Goyal, A.; et al. Consequences of mutant TET2 on clonality and subclonal hierarchy. Leukemia 2018, 32, 1751-1761. [CrossRef] [PubMed]

24. Pellagatti, A.; Roy, S.; Di Genua, C.; Burns, A.; McGraw, K.; Valletta, S.; Larrayoz, M.J.; Fernandez-Mercado, M.; Mason, J.; Killick, S.; et al. Targeted resequencing analysis of 31 genes commonly mutated in myeloid disorders in serial samples from myelodysplastic syndrome patients showing disease progression. Leukemia 2016, 30, 247-250. [CrossRef]

25. Bernard, E.; Nannya, Y.; Hasserjian, R.P.; Devlin, S.M.; Tuechler, H.; Medina-Martinez, J.S.; Yoshizato, T.; Shiozawa, Y.; Saiki, R.; Malcovati, L.; et al. Implications of TP53 allelic state for genome stability, clinical presentation and outcomes in myelodysplastic syndromes. Nat. Med. 2020, 26, 1549-1556. [CrossRef]

26. Malcovati, L.; Papaemmanuil, E.; Ambaglio, I.; Elena, C.; Gallì, A.; Della Porta, M.G.; Travaglino, E.; Pietra, D.; Pascutto, C.; Ubezio, M.; et al. Driver somatic mutations identify distinct disease entities within myeloid neoplasms with myelodysplasia. Blood 2014, 124, 1513-1521. [CrossRef]

27. Yoshida, K.; Sanada, M.; Shiraishi, Y.; Nowak, D.; Nagata, Y.; Yamamoto, R.; Sato, Y.; Sato-Otsubo, A.; Kon, A.; Nagasaki, M.; et al. Frequent pathway mutations of splicing machinery in myelodysplasia. Nature 2011, 478, 64-69. [CrossRef] [PubMed]

28. Carr, M.I.; Jones, S.N. Regulation of the Mdm2-p53 signaling axis in the DNA damage response and tumorigenesis. Transl. Cancer Res. 2016, 5, 707-724. [CrossRef]

29. Nazha, A.; Al-Issa, K.; Hamilton, B.K.; Radivoyevitch, T.; Gerds, A.T.; Mukherjee, S.; Adema, V.; Zarzour, A.; Abuhadra, N.; Patel, B.J.; et al. Adding molecular data to prognostic models can improve predictive power in treated patients with myelodysplastic syndromes. Leukemia 2017, 31, 2848-2850. [CrossRef]

30. Montalban-Bravo, G.; Kanagal-Shamanna, R.; Benton, C.B.; Class, C.A.; Chien, K.S.; Sasaki, K.; Naqvi, K.; Alvarado, Y.; Kadia, T.M.; Ravandi, F.; et al. Genomic context and TP53 allele frequency define clinical outcomes in TP53-mutated myelodysplastic syndromes. Blood Adv. 2020, 4, 482-495. [CrossRef] [PubMed]

31. Haase, D.; Stevenson, K.E.; Neuberg, D.; Maciejewski, J.P.; Nazha, A.; Sekeres, M.A.; Ebert, B.L.; Garcia-Manero, G.; Haferlach, C.; Haferlach, T.; et al. TP53 mutation status divides myelodysplastic syndromes with complex karyotypes into distinct prognostic subgroups. Leukemia 2019, 33, 1747-1758. [CrossRef] [PubMed]

32. Sebaa, A.; Ades, L.; Baran-Marzack, F.; Mozziconacci, M.-J.; Penther, D.; Dobbelstein, S.; Stamatoullas, A.; Récher, C.; Prebet, T.; Moulessehoul, S.; et al. Incidence of 17p deletions and TP53 mutation in myelodysplastic syndrome and acute myeloid leukemia with 5q deletion. Genes Chromosom. Cancer 2012, 51, 1086-1092. [CrossRef] 
33. Meggendorfer, M.; Haferlach, C.; Kern, W.; Haferlach, T. Molecular analysis of myelodysplastic syndrome with isolated deletion of the long arm of chromosome 5 reveals a specific spectrum of molecular mutations with prognostic impact: A study on 123 patients and 27 genes. Haematologica 2017, 102, 1502-1510. [CrossRef] [PubMed]

34. Lodé, L.; Ménard, A.; Flet, L.; Richebourg, S.; Loirat, M.; Eveillard, M.; Le Bris, Y.; Godon, C.; Theisen, O.; Gagez, A.-L.; et al. Emergence and evolution of TP53 mutations are key features of disease progression in myelodysplastic patients with lower-risk $\operatorname{del}(5 q)$ treated with lenalidomide. Haematologica 2018, 103, e143-e146. [CrossRef] [PubMed]

35. Kulasekararaj, A.G.; Smith, A.E.; Mian, S.A.; Mohamedali, A.M.; Krishnamurthy, P.; Lea, N.C.; Gäken, J.; Pennaneach, C.; Ireland, R.; Czepulkowski, B.; et al. TP53 mutations in myelodysplastic syndrome are strongly correlated with aberrations of chromosome 5, and correlate with adverse prognosis. Br. J. Haematol. 2013, 160, 660-672. [CrossRef] [PubMed]

36. Vardiman, J.W.; Arber, D.A.; Orazi, A.; Hasserjian, R.; Borowitz, M.J.; Le Beau, M.M.; Bloomfield, C.D.; Cazzola, M. The 2016 revision to the World Health Organization classifi cation of myeloid neoplasms and acute leukemia. Blood 2016. [CrossRef]

37. Malcovati, L.; Karimi, M.; Papaemmanuil, E.; Ambaglio, I.; Jädersten, M.; Jansson, M.; Elena, C.; Gallì, A.; Walldin, G.; Porta, M.G.D.; et al. SF3B1 mutation identifies a distinct subset of myelodysplastic syndrome with ring sideroblasts. Blood 2015, 126, 233-241. [CrossRef]

38. Harada, H.; Harada, Y.; Niimi, H.; Kyo, T.; Kimura, A.; Inaba, T. High incidence of somatic mutations in the AML1/RUNX1 gene in myelodysplastic syndrome and low blast percentage myeloid leukemia with myelodysplasia. Blood 2004, 103, $2316-2324$. [CrossRef]

39. Christiansen, D.H.; Andersen, M.K.; Pedersen-Bjergaard, J. Mutations of AML1 are common in therapy-related myelodysplasia following therapy with alkylating agents and are significantly associated with deletion or loss of chromosome arm $7 \mathrm{q}$ and with subsequent leukemic transformation. Blood 2004, 104, 1474-1481. [CrossRef]

40. Damm, F.; Chesnais, V.; Nagata, Y.; Yoshida, K.; Scourzic, L.; Okuno, Y.; Itzykson, R.; Sanada, M.; Shiraishi, Y.; Gelsi-Boyer, V.; et al. BCOR and BCORL1 mutations in myelodysplastic syndromes and related disorders. Blood 2013, 122, 3169-3177. [CrossRef] [PubMed]

41. Abuhadra, N.; Mukherjee, S.; Al-Issa, K.; Adema, V.; Hirsch, C.M.; Advani, A.; Przychodzen, B.; Makhoul, A.; Awada, H.; Maciejewski, J.P.; et al. BCOR and BCORL1 mutations in myelodysplastic syndromes (MDS): Clonal architecture and impact on outcomes. Leuk. Lymphoma 2019, 60, 1587-1590. [CrossRef] [PubMed]

42. Malcovati, L.; Papaemmanuil, E.; Bowen, D.T.; Boultwood, J.; Della Porta, M.G.; Pascutto, C.; Travaglino, E.; Groves, M.J.; Godfrey, A.L.; Ambaglio, I.; et al. Clinical significance of SF3B1 mutations in myelodysplastic syndromes and myelodysplastic/myeloproliferative neoplasms. Blood 2011, 118, 6239-6246. [CrossRef] [PubMed]

43. Malcovati, L.; Stevenson, K.; Papaemmanuil, E.; Neuberg, D.; Bejar, R.; Boultwood, J.; Bowen, D.T.; Campbell, P.J.; Ebert, B.L.; Fenaux, P.; et al. SF3B1-mutant MDS as a distinct disease subtype: A proposal from the International Working Group for the Prognosis of MDS. Blood 2020, 136, 157-170. [CrossRef] [PubMed]

44. Kang, M.-G.; Kim, H.-R.; Seo, B.-Y.; Lee, J.H.; Choi, S.-Y.; Kim, S.-H.; Shin, J.-H.; Suh, S.-P.; Ahn, J.-S.; Shin, M.-G. The prognostic impact of mutations in spliceosomal genes for myelodysplastic syndrome patients without ring sideroblasts. BMC Cancer 2015, 15, 484. [CrossRef] [PubMed]

45. Papaemmanuil, E.; Cazzola, M.; Boultwood, J.; Malcovati, L.; Vyas, P.; Bowen, D.; Pellagatti, A.; Wainscoat, J.S.; 5HellstromLindberg, E.; Gambacorti-Passerini, C.; et al. Somatic SF3B1 Mutation in Myelodysplasia with Ring Sideroblasts. N. Engl. J. Med. 2011, 365, 1384-1395. [CrossRef]

46. Thol, F.; Kade, S.; Schlarmann, C.; Löffeld, P.; Morgan, M.; Krauter, J.; Wlodarski, M.W.; Kölking, B.; Wichmann, M.; Görlich, K.; et al. Frequency and prognostic impact of mutations in SRSF2, U2AF1, and ZRSR2 in patients with myelodysplastic syndromes. Blood 2012, 119, 3578-3584. [CrossRef] [PubMed]

47. Kosmider, O.; Gelsi-Boyer, V.; Cheok, M.; Grabar, S.; Della-Valle, V.; Picard, F.; Viguié, F.; Quesnel, B.; Beyne-Rauzy, O.; Solary, E.; et al. TET2 mutation is an independent favorable prognostic factor in myelodysplastic syndromes (MDSs). Blood 2009, 114, 3285-3291. [CrossRef]

48. Smith, A.E.; Mohamedali, A.M.; Kulasekararaj, A.; Lim, Z.Y.; Gäken, J.; Lea, N.C.; Przychodzen, B.; Mian, S.A.; Nasser, E.E.; Shooter, C.; et al. Next-generation sequencing of the TET2 gene in 355 MDS and CMML patients reveals low-abundance mutant clones with early origins, but indicates no definite prognostic value. Blood 2010, 116, 3923-3932. [CrossRef]

49. Guo, Z.; Zhang, S.-K.; Zou, Z.; Fan, R.-H.; Lyu, X.-D. Prognostic significance of TET2 mutations in myelodysplastic syndromes: A meta-analysis. Leuk. Res. 2017, 58, 102-107. [CrossRef]

50. Santamaría, C.; Ramos, F.; Puig, N.; Barragán, E.; De Paz, R.; Pedro, C.; Insunza, A.; Tormo, M.; Del Cañizo, C.; Diez-Campelo, M.; et al. Simultaneous analysis of the expression of 14 genes with individual prognostic value in myelodysplastic syndrome patients at diagnosis: WT1 detection in peripheral blood adversely affects survival. Ann. Hematol. 2012, 91, 1887-1895. [CrossRef]

51. Lin, T.-L.; Nagata, Y.; Kao, H.-W.; Sanada, M.; Okuno, Y.; Huang, C.-F.; Liang, D.-C.; Kuo, M.-C.; Lai, C.-L.; Lee, E.-H.; et al. Clonal leukemic evolution in myelodysplastic syndromes with TET2 and IDH1/2 mutations. Haematologica 2014, 99, 28-36. [CrossRef] [PubMed]

52. Thol, F.; Weissinger, E.M.; Krauter, J.; Wagner, K.; Damm, F.; Wichmann, M.; Göhring, G.; Schumann, C.; Bug, G.; Ottmann, O.; et al. IDH1 mutations in patients with myelodysplastic syndromes are associated with an unfavorable prognosis. Haematologica 2010, 95, 1668-1674. [CrossRef] [PubMed] 
53. Lin, C.-C.; Hou, H.-A.; Chou, W.-C.; Kuo, Y.-Y.; Liu, C.-Y.; Chen, C.-Y.; Lai, Y.-J.; Tseng, M.-H.; Huang, C.-F.; Chiang, Y.-C.; et al. IDH mutations are closely associated with mutations of DNMT3A, ASXL1 and SRSF2 in patients with myelodysplastic syndromes and are stable during disease evolution. Am. J. Hematol. 2014, 89, 137-144. [CrossRef]

54. Thol, F.; Friesen, I.; Damm, F.; Yun, H.; Weissinger, E.M.; Krauter, J.; Wagner, K.; Chaturvedi, A.; Sharma, A.; Wichmann, M.; et al. Prognostic significance of ASXL1 mutations in patients with myelodysplastic syndromes. J. Clin. Oncol. 2011, 29, $2499-2506$. [CrossRef] [PubMed]

55. Thota, S.; Viny, A.D.; Makishima, H.; Spitzer, B.; Radivoyevitch, T.; Przychodzen, B.; Sekeres, M.A.; Levine, R.L.; Maciejewski, J.P. Genetic alterations of the cohesin complex genes in myeloid malignancies. Blood 2014, 124, 1790-1798. [CrossRef] [PubMed]

56. Paquette, R.; Landaw, E.; Pierre, R.; Kahan, J.; Lubbert, M.; Lazcano, O.; Isaac, G.; McCormick, F.; Koeffler, H. N-ras mutations are associated with poor prognosis and increased risk of leukemia in myelodysplastic syndrome. Blood 1993, 82, 590-599. [CrossRef] [PubMed]

57. Murphy, D.M.; Bejar, R.; Stevenson, K.; Neuberg, D.; Shi, Y.; Cubrich, C.; Richardson, K.; Eastlake, P.; Garcia-Manero, G.; Kantarjian, H.; et al. NRAS mutations with low allele burden have independent prognostic significance for patients with lower risk myelodysplastic syndromes. Leukemia 2013, 27, 2077-2081. [CrossRef]

58. Kao, H.W.; Sanada, M.; Liang, D.C.; Lai, C.L.; Lee, E.H.; Kuo, M.C.; Lin, T.L.; Shih, Y.S.; Wu, J.H.; Huang, C.F.; et al. A high occurrence of acquisition and/or expansion of C-CBL mutant clones in the progression of high-risk myelodysplastic syndrome to acute myeloid leukemia. Neoplasia 2011, 13, 1035-1042. [CrossRef] [PubMed]

59. Makishima, H.; Yoshida, K.; Nguyen, N.; Przychodzen, B.; Sanada, M.; Okuno, Y.; Ng, K.P.; Gudmundsson, K.O.; Vishwakarma, B.A.; Jerez, A.; et al. Somatic SETBP1 mutations in myeloid malignancies. Nat. Genet. 2013, 45, 942-946. [CrossRef]

60. Inoue, D.; Kitaura, J.; Matsui, H.; Hou, H.-A.; Chou, W.-C.; Nagamachi, A.; Kawabata, K.C.; Togami, K.; Nagase, R.; Horikawa, S.; et al. SETBP1 mutations drive leukemic transformation in ASXL1-mutated MDS. Leukemia 2015, 29, 847-857. [CrossRef]

61. Fernandez-Mercado, M.; Pellagatti, A.; Di Genua, C.; Larrayoz, M.J.; Winkelmann, N.; Aranaz, P.; Burns, A.; Schuh, A.; Calasanz, M.J.; Cross, N.C.P.; et al. Mutations in SETBP1 are recurrent in myelodysplastic syndromes and often coexist with cytogenetic markers associated with disease progression. Br. J. Haematol. 2013, 163, 235-239. [CrossRef]

62. Damm, F.; Itzykson, R.; Kosmider, O.; Droin, N.; Renneville, A.; Chesnais, V.; Gelsi-Boyer, V.; De Botton, S.; Vey, N.; Preudhomme, C.; et al. SETBP1 mutations in 658 patients with myelodysplastic syndromes, chronic myelomonocytic leukemia and secondary acute myeloid leukemias. Leukemia 2013, 27, 1401-1403. [CrossRef] [PubMed]

63. Bersanelli, M.; Travaglino, E.; Meggendorfer, M.; Matteuzzi, T.; Sala, C.; Mosca, E.; Chiereghin, C.; Di Nanni, N.; Gnocchi, M.; Zampini, M.; et al. Classification and Personalized Prognostic Assessment on the Basis of Clinical and Genomic Features in Myelodysplastic Syndromes. J. Clin. Oncol. 2021, JCO2001659. [CrossRef]

64. Menssen, A.J.; Walter, M.J. Genetics of progression from MDS to secondary leukemia. Blood 2020, 136, 50-60. [CrossRef] [PubMed]

65. Duncavage, E.J.; Jacoby, M.A.; Chang, G.S.; Miller, C.A.; Edwin, N.; Shao, J.; Elliott, K.; Robinson, J.; Abel, H.; Fulton, R.S.; et al. Mutation Clearance after Transplantation for Myelodysplastic Syndrome. N. Engl. J. Med. 2018, 379, 1028-1041. [CrossRef]

66. Martín-Izquierdo, M.; Abáigar, M.; Hernández-Sánchez, J.M.; Tamborero, D.; López-Cadenas, F.; Ramos, F.; Lumbreras, E.; Madinaveitia-Ochoa, A.; Megido, M.; Labrador, J.; et al. Co-occurrence of cohesin complex and Ras signaling mutations during progression from myelodysplastic syndromes to secondary acute myeloid leukemia. Haematologica 2020. [CrossRef]

67. Nazha, A.; Komrokji, R.S.; Meggendorfer, M.; Mukherjee, S.; Al Ali, N.; Walter, W.; Hutter, S.; Padron, E.; Madanat, Y.F.; Sallman, D.A.; et al. A Personalized Prediction Model to Risk Stratify Patients with Myelodysplastic Syndromes. Blood 2018, $132,793$. [CrossRef]

68. Winter, S.; Shoaie, S.; Kordasti, S.; Platzbecker, U. Integrating the "Immunome" in the Stratification of Myelodysplastic Syndromes and Future Clinical Trial Design. J. Clin. Oncol. 2020, 38, 1723-1735. [CrossRef] 